
www.globaljournalseries.com, Email: info@globaljournalseries.com

\title{
ANALYSIS OF RESOURCE USE EFFICIENCY AMONG SOYBEAN (GL YCINE MAX) FARMERS IN GBOKO LOCAL GOVERNMENT AREA OF BENUE STATE, NIGERIA
}

\author{
S. K. UPEV, L. HARUNA AND D. Y. GIROH
}

(Received 5 May 2015; Revision Accepted 17 September 2015)

\begin{abstract}
The study examined the efficiency of resource use in soybean production in Gboko Local Government Area of Benue State, Nigeria. The objectives of the study were to identify and describe the socio economic characteristics of soybean farmers and to determine resource allocation among soybean farmers. Multi-stage random sampling technique was used to select a sample of 120 respondents. Data collected were subjected to Descriptive statistics and production function analysis. The result revealed that $93.3 \%$ of the farmers had one form of formal education, or the other with over $65 \%$ cultivating between $1-4$ hectares. Also, $87.5 \%$ of the farmers were in their active age, and $81.7 \%$ utilized their personal saving as a major source of finance for production. The result of the production function analysis indicated that $87.21 \%$ of the variation in the output of soybean is explained for by the independent variables. Resource-use efficiency revealed that quantity of seed, farm size, herbicide and inorganic fertilizer were underutilized while labour was over utilized. Provision of adequate and timely farming inputs, making loans accessible to farmers and reasonable market price of soybean are essential to boost production.
\end{abstract}

KEYWORDS: Analysis, Resource use efficiency, Farmers, production function analysis, Benue, Nigeria.

\section{INTRODUCTION}

Soybean (Glycine max) is an important crop in the world. The crop can be successfully grown in many states in Nigeria using low agricultural input. Soybean cultivation in Nigeria has expanded as a result of its nutritive and economic importance and diverse domestic usage. It is also a prime source of vegetable oil in the international market. Soybean has an average protein content of $40 \%$ and is more protein-rich than any of the common vegetable or animal food sources found in Nigeria. Soybean seeds also contain about $20 \%$ oil on a dry matter basis, and this is $85 \%$ unsaturated and cholesterol-free (Dugje et al. 2009). Of the oil fraction, $95 \%$ is consumed as edible oil with the rest used for industrial products from cosmetics and hygiene products to paint removers and plastics (Liu 2008). Recently, soybean is found to be an industrially important crop used as anti-corrosion agent, core oil, and bio-fuel due to less or no nitrogen element in the oil, and as disinfectant, in pesticides, printing inks, paints, adhesives, antibiotics and cosmetics (Ngalamu et al. 2012).

The animal protein intake in Nigeria is below the United Nations and Food and Agriculture Organization recommended optimal daily requirement of 20 grams for developing country as against the 75 grams for normal growth and development (FAO, 1992). Although protein in human diet is derived from both plant and animal sources the declining consumption of animal protein due to its high prices requires alternative sources. Soybean provides a cheaper and high protein rich alternative substitute to animal protein. The inclusion of soybean in the carbohydrate rich staple food in Nigeria will increase their protein content (Ashaye, Adegbulugbe and Sanni, 2005 and Ajobo and Akinyemi, 2007). Estimates show that about 925 million individuals are undernourished worldwide (FAO 2010b). Soybean has the potential to address the needs of these individuals through increased local production and consumption of the crop. Development of locally adapted soybean varieties consumed either as cooked mature seeds or immature green seeds would offer vital nutrients and bring balance to the undernourished diet. Other than the high protein content, it also has good amount of calories and fat. It contains the eight essential amino acids and is a rich source of polyunsaturated fatty acids (including the good fat-omega 3) and is free of cholesterol (Food and Agriculture Organization, 1999).

Agricultural research centers like the International Institute of Tropical Agriculture's (IITA) main goal is to generate technologies that will improve productivity, welfare of the farmers, and household nutritional status. Benue state is acclaimed the nation's "food basket" because of its rich and diverse agricultural produce which include yams, rice, beans, cassava, potatoes, maize, Soybeans, sorghum, millet and cocoyam. The state also accounts for over 70 percent of Nigeria's Soybeans production. (Retrieved from: http://www.greaterbenue.com on the $25^{\text {th }}$ February, 2015) The Benue State Agricultural and Rural Development Authority (BNARDA 1995) also reported

S. K. Upev, American University of Nigeria Academy, Yola, Nigeria.

L. Haruna, Department of Agricultural Economics and Extension, Modibbo Adama University of Technology PMB 2076, Yola, Nigeria.

D. Y. Giroh, Department of Agricultural Economics and Extension, Modibbo Adama University of Technology PMB 2076, Yola, Nigeria. 
that Benue state accounts for over $70 \%$ of soybean production in Nigeria. Similarly, a survey conducted and reported by IITA in 1989 revealed that Benue State remained the major producer of soybean in Nigeria. The citizens of the state especially in the rural areas are predominantly engaged in farming activities.

Production efficiency means the attainment of production goals without waste. Efficiency is often used synonymously with that of productivity which relates output to input. In agriculture, the analysis of efficiency is generally associated with the possibility of farm production to attain optimal level of output from a given bundle of input at least cost. Resource use efficiency means how efficiently the farmer can use his resources in production process. Analysis of resource use is very important because our resources are limited. In order to achieve optimum production level, resources must be available and whatever quantities of available resources must be used efficiently. Successful result oriented farm planning and policies require the knowledge of productivities of farm resources to know the resources whose quantity or rate of use should be increased or decreased (Sani et al. (2010) in (Alimi, 2000). Mugabo et al. (2014) in their study of Resource use Efficiency in Soybean Production in Rwanda reported that with an elasticity of 0.46 , plot size was the most important factor of soybean production. It was closely followed by intermediate inputs (fertilizers, pesticides and seeds), with a coefficient of 0.44 . When intermediate inputs were decomposed, fertilizers with an elasticity of 0.062 appears to contribute more to soybean production than pesticides (0.057) and seeds (0.034). Technical inefficiency was responsible for at least $93 \%$ of total variation in soybean output among the survey farmers. The relative efficiency (allocative efficiency) of resource use, expressed as the ratio of marginal value product (MVP) to marginal factor cost (MFC), were 1.73 for soybean plot size, 1.36 for fertilizers, and 1.92 for pesticides. These indicate that too little of these inputs are being used in relation to the prevailing market conditions.

Also, Olorunsanya et al. (2009), in their study revealed the marginal analysis of resource utilization for soybean in Kwara State, North Central Nigeria, and showed that there was inefficiency in the utilization of resources in the area with land being underutilized and other resources labour, seed and herbicide been over utilized. Findings from most of the existing studies revealed that farmers are inefficient in their resource allocation. Some of the different variables that leads to inefficiency as reported by most studies majorly are socio-economic variables such as farmers' age, level of education, farm size, number of hired workers, years of farming experience, access to extension contact, land ownership, cooperative membership etc. All these negatively affect the efficacy of resource use by the peasant farmers.

In order to ensure efficiency of resource use by farmers in Benue state, the Benue State Agricultural and Rural Development Authority (BNARDA) to serve as a research centre too, was established by the Benue State government as a Parastatal under Edict No. 7 of 1985 targeting essentially the small scale farmers. BNARDAs overall objectives are to promote increased agricultural production in the state and raise the income and standard of living of the farmers. In order to make the impact of BNARDA felt in the whole state it is operated on the basis of three agro-development zones, namely, Central Zone with headquarters at Otukpo, Eastern Zone with headquarters at Adikpo, and Northern Zone with its headquarters located at Gboko.

Despite the efforts of BNARDA in the state and other agricultural research institutes, soybean farmers are still not efficient in the use of available resources and in an attempt to address this, the study was carried out with the broad objective to determine the Analysis of Resources use Efficiency among Soybean Farmers in Gboko Local Government Area of Benue State, Nigeria. The specific objectives were to describe the socioeconomic characteristics of soybean farmers in the study area and determine the efficiency of resource use among the soybean farmers.

\section{METHODOLOGY}

The study was conducted in Gboko Local Government Area of Benue State. Gboko Local Government is located between latitudes $6^{0} 3^{\prime}$ and $8^{0} 1^{\prime}$ North of the Equator and longitudes $8^{\circ}$ and $10^{\circ}$ East of the Greenwich Meridian (Benue State Government Diary, 2009). The Local Government is bounded by Tarka and Guma local government's Areas to the north, Ushongo Local Government to the south, Buruku Local Government to the East, and Konshisha Local Government to the South- West while Gwer Local Government lies in the West. The local government derived its name from the sceneries common trees known as Gboko which grows especially on the hills at the north western part of the area (Abaya, 2013). The local government covers a land mass of $2264 \mathrm{~km}^{2}$ with a population of 361,325 people (National Population Commission, NPC, 2006) making Gboko one of the most populous Local Government Areas in Benue State.

The Local Government Area has a tropical climate marked by two distinct seasons (the wet or rainy season and the dry season). The rainy season lasts from April to October with an August break. The annual rainfall is in the range of $1500 \mathrm{~mm}$ to $1800 \mathrm{~mm}$. The dry season begins in November and ends in March with a dust laden spell, the Harmattan wind that blows from across the Sahara. The temperature fluctuates between $23^{\circ} \mathrm{C}$ and $35^{\circ} \mathrm{C}$. Because the soil is rich, sandy loamy and very fertile for most savannah food crops, Gboko farmers produce root crops such as yams, cassava, and sweet potatoes in large quantities beyond subsistence level. The rich agricultural soil of the local government ranks Gboko as the highest producers of soybeans as well as other grains/seeds like maize, guinea corn, groundnut etc. (Abaya, 2013).

The population of this study consisted of soybean farmers in Gboko Local Government Area of Benue State. Gboko Local Government Area has six districts and seventeen wards. The districts are; Ipav, Mbayion, Yandev, Township, Mbatyav and Mbateriev while the wards include; Gboko North/West, Gboko South, Gboko East, Gboko Central, Igyorov, Mbakpegh, Mbadim, Mbaanku, Mbaavarakaa, Mbakwen, Mbadam, Mbatyu, Ukpekpe, Mbatsegh, Mbatan, Mbaiwar and Utabar Mbateriev. Multi-stage random sampling technique was used to select respondents for the study. In the first stage, six out of the seventeen wards in 
Gboko Local Government Area were randomly selected, that is, one wards each from the six districts. In the second stage, two villages were randomly selected from each of the six wards giving a total of twelve villages. A total of 350 farmers were found to be involved in soybean production in the selected villages (BNARDA, 2012). A total of 120 questionnaires were administered to randomly selected farmers in the villages. The distribution was proportionately done based on the number of farmers in the selected villages and all the questionnaires were retrieved and used for the analysis. The distribution of sample in the twelve (12) selected villages is presented in Table 1.

Table 1: Distribution of Sample in the 12 Selected Villages in the Study Area

\begin{tabular}{|c|c|c|c|c|}
\hline $\mathbf{S} / \mathbf{N}$ & Wards & Villages & No. of farmers & No. sampled \\
\hline \multirow[t]{3}{*}{1} & Igyorov & Mbadim & 41 & 14 \\
\hline & & Mbangu & 23 & 8 \\
\hline & & Subtotal & 64 & 22 \\
\hline \multirow[t]{3}{*}{2} & Gboko North-West & Anikyenge & 52 & 18 \\
\hline & & Ayaba & 30 & 10 \\
\hline & & Subtotal & 82 & 28 \\
\hline \multirow[t]{3}{*}{3} & Mbadim & Akpagher & 47 & 16 \\
\hline & & Ikumbur & 35 & 12 \\
\hline & & Subtotal & 82 & 28 \\
\hline \multirow[t]{3}{*}{4} & Mbakwen & Mbajen & 38 & 13 \\
\hline & & Mbajor & 20 & 7 \\
\hline & & Subtotal & 58 & 20 \\
\hline \multirow[t]{3}{*}{5} & Utabar & Mbaanyabe & 23 & 8 \\
\hline & & Mbatitiv & 18 & 6 \\
\hline & & Subtotal & 41 & 14 \\
\hline \multirow[t]{4}{*}{6} & Mbatyu & Tsekucha & 14 & 5 \\
\hline & & Amua & 9 & 3 \\
\hline & & Subtotal & 23 & 8 \\
\hline & & Grand Total & 350 & 120 \\
\hline
\end{tabular}

Source: Field survey, 2014

Descriptive statistics made use of percentages and means to describe the socio-economic characteristics of soybean farmers while the production function analysis was used to examine resource allocation pattern among respondents. Four functional forms of production function analysis namely linear, semi-log, double log and exponential function were tried. The Cobb-Douglas or double log gave the best fit and is expressed explicitly as $\log Y=B o+B_{1} \log X_{1}+B_{2} \log$ $X_{2}+B_{3} \log X_{3}+\ldots .+B_{5} \log X_{5}+U_{i \ldots .}$ (3.1) Where: $Y=$ Output of soybean in $(\mathrm{kg}), X_{1}=$ Quantity of soybean seed used (kg), $X_{2}=$ Farm size (ha), $X_{3}=$ Quantity of herbicides used (litres), $X_{4}=$ Labour in man-days, $X_{5}=$ Quantity of inorganic fertilizer used $(\mathrm{kg}), \mathrm{B}_{0}=$ Constant, $\mathrm{B}_{1}-\mathrm{B}_{5}=$ coefficient of independent variables to be estimated and $\mathrm{U}_{\mathrm{i}}=$ Error term.

Regression coefficients $\left(b_{1}-b_{5}\right)$ from the regression analysis were used to compute the Marginal Value Product (MVP) for each input used. The computation of MVP and the Marginal Factor Cost (MFC) are as follows:

$M V P=M P P_{x} P_{y}$

$M F C=\mathrm{P}_{i}$

Where:

$P_{y}=$ Unit price of $100 \mathrm{~kg}$ bag of soybean

$M P P=$ Marginal Physical Product $\frac{d y}{\left(d x_{i}\right)}$ to be estimated based on the selected functional form (i.e., the product of regression coefficient and the mean output).
$M F C=$ Unit cost of that particular input

The ratio of the MVP to MFC was used to determine the efficiency resources were used. That is,

$r=\frac{M V P}{M F C}$

Where: $r=$ efficiency parameter, $M V P=$ the Marginal Value Product, $M F C$ = the Marginal Factor Cost of input (input prices).

\section{Decision Rule}

i. If the efficiency ratio $(r)=1$ : there is efficiency of resource-use

ii. If the efficiency ratio $(r)>1$ : the resource is under-utilized

iii. If the efficiency ratio $(r)<1$ : the resource is over-utilized (Moses and Adebayo, 2007; Goni and baba, 2007).

The MVP $P_{x}$ for each input used will be computed using the regression coefficients of each input. The MFC is the prevailing market price of each input or geometric mean value of the input $(x)$.

\section{Socio-economic Characteristics of Respondents}

The study revealed that $82.5 \%$ of the respondents were male and $82.5 \%$ were equally married indicating that soybean production in the study area is dominated by the male although the female plays complimentary roles. Ndaghu et al. (2009) reported that males are the most household heads and they are 
responsible for major production decisions. The majority $68.3 \%$ of the respondents were aged $15-44$ years, while the average age of the respondents was 39 years indicating that majority of the soybean farmers in the study area were within the most active age of the population. It also indicates that their productivity is expected to increase because younger farmers adopt new agricultural innovations easier than older farmers. The majority $93.3 \%$ had one form of formal education or the other. Ajao et al. (2012) stated that the more educated farmers are, the higher there utilization of soybean production process. The predominant land tenure system was inheritance; representing 65\%. Ojo et al. (2008) and Omonona et al. (2010) both reported that majority of their respondents acquired their land through inheritance and family land. The mean farm size was 3.4 ha, with $71.6 \%$ of the respondents having a farm size of 1-4 ha. The major source of finance was through personal savings, $81.7 \%$. This could negatively affect farmers especially when there is need to buy new farm inputs. Also, $84.2 \%$ of the respondents used improved seed in cultivating soybean and majority $72.5 \%$ had no personal access to extension personnel. Similarly, $60 \%$ had farming as their main occupation while $49.2 \%$ made use of family labour in the cultivation of soybean. The mean age of farming experience was 18 years and $35 \%$ of the respondents were having 21 years and above. Tashikalma (2007) also reported that farmers with more years of farming experience are better in terms of handling farm operations compared to farmers with fewer years of farming experience. Also, only $39.8 \%$ were members of a cooperative association.

Table 2: Descriptive Statistics of Soybean Farmers

\begin{tabular}{|c|c|c|}
\hline Item & Frequency & Percentage \\
\hline \multicolumn{3}{|l|}{ Gender } \\
\hline Male & 99 & 82.5 \\
\hline Female & 21 & 17.5 \\
\hline Total & 120 & 100 \\
\hline \multicolumn{3}{|l|}{ Marital status } \\
\hline Married & 99 & 82.5 \\
\hline Single & 12 & 10.0 \\
\hline Widow & 6 & 5.0 \\
\hline Divorced & 3 & 2.5 \\
\hline Total & 120 & 100 \\
\hline \multicolumn{3}{|l|}{ Age (years) } \\
\hline $15-24$ & 10 & 8.3 \\
\hline $25-34$ & 24 & 20 \\
\hline $35-44$ & 48 & 40 \\
\hline $45-54$ & 33 & 27.5 \\
\hline$\geq 55$ & 5 & 4.2 \\
\hline Total & 120 & 100 \\
\hline \multicolumn{3}{|l|}{ Level of education } \\
\hline No formal education & 8 & 6.7 \\
\hline Primary education & 29 & 24.2 \\
\hline Secondary education & 64 & 53.3 \\
\hline Tertiary education & 19 & 15.8 \\
\hline Total & 120 & 100 \\
\hline \multicolumn{3}{|l|}{ Mode of land acquisition } \\
\hline Inherited/family land & 78 & 65.0 \\
\hline Leased land & 34 & 28.3 \\
\hline Gift & 8 & 6.7 \\
\hline Total & 120 & 100 \\
\hline \multicolumn{3}{|l|}{ Farm size } \\
\hline $1-2$ & 49 & 40.8 \\
\hline $3-4$ & 37 & 30.8 \\
\hline $5-6$ & 23 & 19.2 \\
\hline$\geq 7$ & 11 & 9.2 \\
\hline Total & 120 & 100 \\
\hline \multicolumn{3}{|c|}{ Farming experience (years) } \\
\hline $1-10$ & 24 & 20 \\
\hline $11-20$ & 54 & 45 \\
\hline $21-30$ & 30 & 25 \\
\hline$\geq 31$ & 12 & 10 \\
\hline Total & 120 & 100 \\
\hline \multicolumn{3}{|l|}{ Source of labour } \\
\hline Family labour & 59 & 49.2 \\
\hline Hired labour & 16 & 13.3 \\
\hline Family and hired labour & 33 & 27.5 \\
\hline Group contribution & 12 & 10.0 \\
\hline Total & 120 & 100 \\
\hline \multicolumn{3}{|l|}{ Type of seed used } \\
\hline Improved seed & 101 & 84.2 \\
\hline Local variety & 19 & 15.8 \\
\hline Total & 120 & 100 \\
\hline
\end{tabular}




\section{Production function analysis}

Production function analysis was used in examining the influence of various inputs $\left(X_{1}-X_{5}\right)$ on the output of soybean. The data obtaVined were subjected to four functional forms namely linear, semilog, double log and exponential function and Double log gave the best fit based on a priori expectation of fulfilling economic, statistical and econometric criteria with respect to signs, magnitude and significance of the regression coefficients and the result is presented in Table 3. The coefficient of multiple determination, (adjusted $R^{2}$ in the model was 0.872058 meaning that $87.21 \%$ of the variation in the output $Y$ is explained by the independent variables. The entire coefficients in the chosen model carry the expected positive sign. The production function estimates indicates the relative importance of factor inputs in soybean production. From the result in Table 3, farm size $\left(X_{2}\right)$ factor input appears to be the most important factor of production with an elasticity of 0.470 . The positive coefficient of farm size conforms to a priori expectations and is significant at $1 \%$ probability level. The significance of this variable is as a result of its importance in crop production since its shortage would not only pose a direct negative effect on production but also an indirect negative effect on output through reducing the marginal productivity of non-land input (Shehu and Mshelia, 2007). The coefficient of seed $\left(X_{I}\right)$ was positive $(0.388761)$ and is statistically significant at $1 \%$ implying that a unit increase in the quantity of soybean seed will cause a corresponding increase of $0.388761 \mathrm{~kg}$ ceteris paribus. The coefficient of labour input $\left(X_{4}\right)$ is also positive (0.033) and statistically significant at $1 \%$ level, suggesting its importance in agricultural production. The coefficient of inorganic fertilizer $\left(X_{5}\right)$ is also positive $(0.192)$ and statistically significant at $1 \%$ meaning that fertilizer increases yield (output) when applied appropriately. In this analysis, a 1\% increase in fertilizer application by soybean farmers would increase output by $19.2 \%$. Similarly, the coefficient of herbicide used $\left(X_{3}\right)$ is positive $(0.154)$ and is statistically significant at $5 \%$ level, meaning that a $5 \%$ increase in the quantity of herbicide would bring about $15.3 \%$ increase in output of soybean if applied appropriately by the farmers. Ani et al. (2012) also reported on similar findings on leguminous crops in Benue state.

Table 3: Regression Result Double log function for Soybean Farmers

\begin{tabular}{|c|c|c|c|}
\hline Variable & Coefficient & Standard Error & t-value \\
\hline Quantity seed $\left(X_{1}\right)$ & 0.388761 & 0.075586 & $5.143274^{\star \star \star}$ \\
\hline Farm Size $\left(X_{2}\right)$ & 0.470114 & 0.065685 & $7.157072^{\star * *}$ \\
\hline Herbicide $\left(X_{3}\right)$ & 0.153530 & 0.076803 & $1.999003^{\star *}$ \\
\hline Labour $\left(\mathrm{X}_{4}\right)$ & 0.033065 & 0.004461 & $7.411400^{\star * *}$ \\
\hline Inorganic fertilizer $\left(X_{5}\right)$ & 0.192362 & 0.037259 & $5.162815^{\star \star *}$ \\
\hline$R^{2}$ & 0.880659 & & \\
\hline Adjusted $\mathrm{R}^{2}$ & 0.872058 & & \\
\hline S.E of regression & 0.056498 & & \\
\hline F-Value & $528.7607^{\star \star \star}$ & & \\
\hline Durbin-Watson Stat & 1.493442 & & \\
\hline
\end{tabular}

\section{Marginal productivity of resource use in soybean production}

The marginal physical product (MPP) for input utilization was derived from the estimated regression coefficients and the arithmetic mean values of output and inputs as shown in Table 5. The marginal physical product for each of the resources was obtained based on the Double log production function. Farm size (hectares) gave the highest value of marginal physical product (233.49). The implication is that an increase in farm size by one hectare would result in extra $233.49 \mathrm{~kg}$ of soybean. Efficiency of the marginal value product
(MVP) of seed $\left(X_{1}\right)$, farm size $\left(X_{2}\right)$, herbicide $\left(X_{3}\right)$, and inorganic fertilizer $\left(X_{5}\right)$ to their corresponding marginal factor costs (MFC) revealed that the ratio was greater than unity for these inputs, indicating that the inputs were both underutilized. On the other hand, the efficiency of the marginal value product (MVP) of labour $\left(\mathrm{X}_{4}\right)$ to its corresponding marginal factor costs (MFC) showed that the ratio was less than unity for this input implying that it was over utilized. Optimal resource allocation requires that the marginal value product (MVP) be equal to marginal factor cost (MFC). 
Table 4: Estimated Marginal Physical Product and Resource Use Efficiency

\begin{tabular}{|c|c|c|c|c|c|c|}
\hline Variable & $\begin{array}{l}\text { Production } \\
\text { elasticity }\end{array}$ & MPP & MVP & MFC & MVP/MFC & $\begin{array}{l}\text { Resource } \\
\text { efficiency }\end{array}$ \\
\hline Seed $\left(X_{1}\right)$ & 0.388761 & 12.54 & $94,014.37$ & $6,469.4$ & 14.53 & Under- \\
\hline Farm size & & & & & & utilized \\
\hline$\left(\mathrm{X}_{2}\right)$ & 0.470114 & 233.49 & $163,442.97$ & 4200 & 38.91 & Under- \\
\hline $\begin{array}{l}\text { Herbicide } \\
\left(X_{3}\right)\end{array}$ & 0.153530 & 77.28 & $66,979.45$ & $5,130.69$ & 13.05 & $\begin{array}{l}\text { utilized } \\
\text { Under- }\end{array}$ \\
\hline $\begin{array}{l}\text { Labour } \\
\left(X_{4}\right)\end{array}$ & 0.033065 & 1.16 & 463.47 & 34,016 & 0.01 & $\begin{array}{l}\text { utilized } \\
\text { Over-utilized }\end{array}$ \\
\hline $\begin{array}{l}\text { Fertilizer } \\
\left(X_{5}\right)\end{array}$ & 0.192362 & 2.33 & $12,816.31$ & 5,333 & 2.40 & $\begin{array}{l}\text { under- } \\
\text { utilized }\end{array}$ \\
\hline
\end{tabular}

Source: Field Survey, 2014

\section{CONCLUSION}

The study examined the analysis of resource use efficiency among soybean farmers in Gboko local government area of Benue state, Nigeria. The socio economic analysis of the respondents revealed that the majority $68.3 \%$ were young with mean age of 39 years. $82.5 \%$ were married and also $82.5 \%$ of the farmers were male. Majority of the farmers were small scale farmers and also the majority $93.3 \%$ had one form of education or the other. The major source of financing production was personal saving and the predominant land tenure system was inheritance. The majority of the farmers $72.5 \%$ had no personal access to extension personnel and only $39.8 \%$ belonged to a cooperative society. The production function analysis also revealed that quantity of seed used, farm size, herbicide and inorganic fertilizer were underutilized whereas labour was over utilized. The following recommendations are suggested; appropriate use of quantity of seed/ha, efficient use of available farm size for planting soybean as sparsely planted by some farmers, inadequate application of fertilizer and herbicide should be adjusted to bring output to optimal level. Also the standard man days of labour should be utilized in soybean production to avoid its overutilization and the surplus hours channel into other farming activities. Or necessary adjustments of the production inputs should be made to bring production to optimal level. Farmers are also encouraged to form cooperative groups to help them buy farm inputs (fertilizer, herbicide) etc. at reasonable prices and jointly market their produce at favourable prices too to eliminate the role of middlemen. Cooperative societies also will help the farmers' access agricultural loans at reasonable interest rates too. Additionally, favourable prices of soybeans could attract the youths into its production and will correct the existing scenario that farming is left for the weak and old in our rural communities. Lastly the mode of land ownership, inheritance, should be addressed by the government at all levels to facilitate additional production of soybean in the study area.

\section{REFERENCES}

Abaya, J. A., 2013. An Update Profile of Gboko Local Government Council.
Ajao, A. O., Ogunniyi1, L. T and Adepoju, A. A., 2012. Economic Efficiency of Soybean Production in Ogo-Oluwa Local Government Area of Oyo State, Nigeria. American Journal of Experimental Agriculture, 2, (4): 667-679.

Ajobo, T and Akinyemi, A., 2007. Soybean: Food that prevents cancer, diabetes, menopausal problem. The Tribune, June 6, 2007, page 2.

Ani, D. P., Ochalibe, A. I And Ogebe, F. O., 2012. Profitability of Food Legumes Crops In Benue State. International Journal of Development Studies, 6, (5): 8-10.

Ashaye, O. A., Adegbulugbe, T. A and Sanni, S., 2005. Assessment of soybean processing technologies in Ilorin East and West Local Government Area of Kwara State. World Journal of Agricultural Science, 1, (1): 59-61.

Benue State Government., 2009, Diary.

Benue State Agricultural and Rural Development Authority, BNARDA., 1995. Annual Report BNARDA, Makurdi, Nigeria.

BNARDA., 2012. Soybean yield in metric tons in Benue State.

Dugje, I. Y., Omoigui, L. O., Ekeleme, F., Bandyopadhyay, R., Lava Kumar, P and Kamara, A. Y., 2009. Farmers Guide to Soybean Production in Northern Nigeria. International Institute of Tropical Agriculture, Ibadan, Nigeria: PP1.

Food and Agriculture Organization, FAO., 1992. FAO Production Year Book Vol. 45, Rome.

Food and Agricultural Organization of the United Nations., 1999. Manual for training in Seed Technology and seed production. Trivevedi, R. K., Usman I. A. and Umeh J.C. (Eds) 69.

FAO., 2010b. The state of food insecurity in the world. Rome: FAO. 
http://www.greaterbenue.com Retrieved on the $25^{\text {th }}$ February, 2015.

Liu, K., 2008. Food use of whole soybeans. In L. Johnson, P. J. White, \& R. Galloway (Eds.), Soybeans: chemistry, production, processing, and utilization (pp. 441 - 446). Urbana, IL: AOCS Press.

Moses, J and Adebayo, E. F., 2007. Efficiency of Factors determining Rain-fed Rice production in Ganye Local Government Area of Adamawa State, Nigeria. Journal of sustainable Development in Agriculture and Enviroment. 3, $20-30$.

Mugabo Josaphat., Eric Tollens., Jonas Chianu., Ajuruchukwu Obi and Bernard Vanlauwe., 2014. Resource Use Efficiency in Soybean Production in Rwanda. Journal of Economics and Sustainable Development 5, (6): 2014.

National Population Commission, NPC., 2006. National Population Census, Federal Republic of Nigeria, Official Gazette, Vol. 94, Lagos.

Ndaghu, A. A., Maurice, D. C and Zubairu, E. A., 2009. Adoption of the New Rice for Africa (NERICA) Variety among small-scale farmers in Taraba State, Nigeria. Nigerian Journal of Tropical Agriculture. (11): 259-263.

Ngalamu, T., Meseka, S and Ashraf, M. 2012. Performance of soybean (Glycine max L Merrill) genotypes under different planting dates in Sennar State of the Sudan. Journal of Applied Biosciences (49): 3363-3370.
Ojo, M. A., Salami, A. E and Mohhamed, U. S., 2008. Profitability, inputs Elasticities and Resource use Efficiency in Small Scale Cowpea production in Niger State, Nigeria. Journal of Agricultural and Social Research, 8, (2):

Olorunsanya, E. O., Babatunde, R. O., Orebiyi, J. S., Omotosho, J. O., 2009. Economic analysis of soybean production in Kwara State, North Central Nigeria. Global Approaches to Extension Practice (GAEP), 5, (2): 45-53.

Omonoma, B. T., Egbetokun, O. A and Akanbin, A. T., 2010. Farmers Resource Use and Technical Efficiency in Cowpea Production in Nigeria. Economic Analysis Policy, 40, (1): 87-95.

Sani, A., Yakubu, A. A and Bello, H. M., 2010. Resource-use Efficiency in Rice production under small scale irrigation in bunkure local Government area of Kano State. Nigerian Journal of Basic Applied Science, 18, (2): 292 296.

Tashikalma, A. K., 2010. Comparative Analysis Rain-fed and irrigated Food Crops in Adamawa State, Nigeria. Unpublished doctoral thesis, Department of Agricultural Economics, ATBU. 